\title{
EFFECT OF SOME EDAPHIC FACTORS AND THE DISTRIBUTION OF YELLOW-NECKED FIELD MOUSE (Apodemus flavicollis argyropuli) IN FIELD CROP BIOTOPES
}

\author{
Amin A. KHEdher ${ }^{*}$ and AKram A. KhalaF ${ }^{* *}$ \\ *Dept. of Recreation and Ecotourism, College of Agricultural Engineering Sciences, University of \\ Duhok, Kurdistan Region-Iraq. \\ ** Dept. of Soil and Water Sciences, College of Agricultural Engineering Sciences, University of \\ Duhok, Kurdistan Region-Iraq.
}

(Received: April 16, 2019; Accepted for Publication: September 1, 2019)

\begin{abstract}
Accurate conservation and management of yellow-necked field mouse requires ecological knowledge of its habitat. In the present research study, we tried to assess the effect of some edaphic factors (soil texture, organic matter, $\mathrm{CaCO3}$, bulk-, and particle densities, and porosity) as independent variables on the burrow structures (pathway length, total length, depth, and secondary entrances), as dependent variables. Regression models was carried out on 25 burrows distributed on 5 suffered locations from the species damages (Sumail, Girshin, and Faishkhabour in Duhok; and Engineering College fields, and Shawis in Erbil).

Two types of burrows (simple: only main entrance, and complex: has a main entrance and one or more secondary entrances or tunnel branches), and three types of burrow distribution (Insular, Cumulative, and Unequal) were identified in studied areas, which can be turned to the soil features and the quantity, quality as well as the distribution of food sources. The results of this study indicate the following main interaction correlations: Negative correlations have been found between organic matter and porosity; (silt) ${ }^{4}$ positively correlated with pathway length; organic matter and bulk density negatively- but (silt) ${ }^{3}$ and $\mathrm{CaCO} 3$ positively correlated with total length; the number of secondary entrances and sand positively- while $\mathrm{CaCO} 3$ and bulk density negatively correlated with the depth; sand and silt positivelybut $\mathrm{CaCO3}$ and porosity negatively correlated with the number of secondary entrances. Pearson correlation coefficients showed the strongest positive correlation between the total length and pathway length, as well as between clay and organic matter; and the strongest negative correlation between bulk density and porosity.

Our findings could provide additional habitat information for integrating management tools, with a particular focus on the relationships between effective dependent and independent factors.
\end{abstract}

KEYWORDS: Burrows, habitat, Edaphic Factors, Secondary Entrances, Spatial Dispersion, Tunnels, Yellow-Necked Field Mouse, and Kurdistan Region.

https://doi.org/10.26682/ajuod.2019.22.2.2

\section{INTRODUCTION}

$\mathbf{T}$ The studied species, belongs to Muridae family and Rodentia order. Apodemus flavicollis argyropuloi (Ellerman and Morison Scott, 1951), and A. flavicollis parvus (Vinogradov and Argyropulo), 1941, are infraspecific taxa, and are synonyms for $A$. ponticus (Sviridenko, 1936), (ITIS- Integrated Taxonomic Information System- Report: Taxonomic Serial No. 585139). The names argyropuli (Ellerman and Morison Scott, 1951), and argyropuloi (Heptner, 1948, brevicauda Sviridenko, 1936, and Harisson and Bates, 1991), are synonyms and were proposed to replace parvus. A. flavicollis argyropuloi, and A. flavicollis parvus are invalid now, (Abs.Works Zool.Inst. Moscow State Univ...3:103).

On the other hand (Robert H. Hatt, 1959, in his book (The Mammals of Iraq, 1959, p.84) mentioned that A. flavicollis argyropuli Ellerman and Morison Scott, Checklist Palearctic Mamm., 1951, p.568. New name for A. flavicollis parvus Vinogradov and 
Argyropulo), (A. flavicollis parvus Vinogradov and Argyropulo, Fauna U.S.S.R., N.S., 29 (1941): 163. Type locality: Delizhan, Armenia, U.S.S.R.).

The presence of species is reported at first time in oak-and cultivated lands of Iraqi Kurdistan by (Robert T. Hatt, 1959).

A. flavicollis argyropuli, found in Iraq (Haj Omran, Hubbard, and Sarsank), Many specimens were caught in stream sides and dense gardens and in the drier open oak forests of mentioned places, (Robert T. Hatt, 1959). Geographic distribution of A. ponticus (synonym of A. flavicollis argyropuloi, on which the latter one is synonym for A. flavicollis argyropuli ), is Europe and Northern Asia (excluding China), and its status according to IUCN, ver. 3.1 Lower Risk (Ic).

While A. flavicollis is native to Europe and western Asia, (Musser, G.G.; Carleton, M.D. 2005). The range of $A$. flavicollis includes the more mountainous parts of Western Europe with the exception of northern Scandinavia, southern Spain and western France. This mouse occurs in Great Britain but not in Ireland, and it is also absent from a number of Mediterranean islands. In Asia, its range extends eastward to the Ural Mountains and it is also found in Turkey, Armenia, Iran, Syria, Lebanon and Israel. It is mostly a woodland species, often living near the forest verge, but in mountainous regions, it occupies any part of the forest. It is usually found in mature deciduous woodland is also found in scrubby areas, hedgerows, orchards and plantations. It favors areas where there are large, nut-bearing trees such as the oak and the hazel, (Amori, G. et al. 2008). It is also found in parks and gardens and beside alder-fringed streams, (Konig, Claus, 1973).

In favorable conditions usually seen in old deciduous forests. Yellow-necked field mouse $A$. flavicollis argyropuli (Ellerman and Morison Scott, 1951), is a small wild dislike open landscapes, and considered as silvicol mammalian species. They had often seen in houses (info@themmalsociety.org www.mammal.org.uk 0238023 7874). Climatic factors seem to be as limited factors for its range that favors wetter colder areas. Their distribution is also associated with that of old woodland sites (Jalil, 1987); (Michal K., 1976). They have wide diverse food like seeds, fruits, seedlings, buds, and some vertebrates (info@themmalsociety.org www.mammal.org.uk $023 \quad 8023 \quad 7874)$. In addition to that are omnivorous and high mobility nocturnal animals. Their tunnels always wavy some have several entrances. The animal can take a benefit from deep wide cracks in the soil as tunnels (Robert, 1959); (Szeky Pal, 1983). The distribution and abundance of organisms influenced by the soils associated with ecosystems (Erick et al., 2003).There are some direct and indirect interactions between soil and wildlife. Fossorial animals depend on soil features for the integrity of their tunnels and dens. They dig their burrows in several kinds of soils (Abdul-Husain, 1994).

Edaphic factors are soil abiotic factors, which are the output of chemical and physical factors. Soil biotic factors are soil-living organisms which consist of fauna and flora. Therefore the burrowing animal plays a large role in megafauna (Erick G. B. et al., 2003). The studied locations are located within agricultural areas, and the burrowing animal was found within agro-ecosystems, so it will be one of the agrozoo-cenosis. Agro-bio-cenosis can be affected by ecological factors and interrelationship interactions. The relationship between habitat edaphic factors and the local distribution and abundance of fossorial animal have great importance. Different damages caused by these mice to field crops in different agricultural biotopes were the main motivation of this study.

The justifications of this study can be concluded in the damages of this species to the field crops in studied areas, and a lack of ecological information about this species, which can motivate us to put suitable ecological solutions for animal damages, and prepare a wise protection policy for field crops. Therefore the aim of this study is to assess the impact of organic matter, $\mathrm{CaCO} 3$, bulk density, particle density, porosity, sand, silt, and clay on some tunnel dimensions (i.e. pathway length, total length, depth, and the number of secondary entrances) in relation to the distribution of yellow-necked field mice in agricultural biotopes.

\section{MATERIAL AND METHODS 2.1. Fieldworks \\ 2.1.1. Study area:}

Five locations selected for this study project; three were located in Duhok Governorate (Sumail, Girshin, and Faishkhabour) and two 
locations located in Erbil Governorate (Engineering College fields and Shawis) in Kurdistan Region, Iraq.

The locations were located within cereal field crop habitats. Girshin and Faishkhabour situated in gentle slope plane lands, which are in the vicinity of feet-hills, others have a lesser slope. All identified regions are managed under agricultural systems.

\subsubsection{Identifying the species:}

Alive yellow-necked field mouse caught from hot (active) burrows to distinguish the species.

Three simple ways were used for this purpose:

1. Morphological features of the animal.

An external sight of skins from hundred specimens used for this purpose, on which most easily distinguished, depending on the presence or absence of yellow crossing stripe and a complete collar of yellowish fur on the breast, in addition to other morphological dimensions, (Habil and Hans, 1973). Ten spring wooden cage traps $(20 * 10 * 10 \mathrm{~cm})$ used to capture animals alive in each trial and site, by using oiled bread as bait. Each trap was covered with light weeds. The traps cleaned after each trapping with an interval of two days between the first and second trial in September and October, (Montgomery, W.I., 1979).

2. Using of some biometric measurements.

Four measurements (total length, tail length, length of hind foot, and length of ear) are recorded. All measurements are taken in millimeters. We applied measurements, which are in standard use in North America, because they are easier to apply, (Robert E. M., 2001).

3 . Observations on the entrances of burrows. Monitoring of animals were done while digging the burrows especially in spring when usually digging taken place.

2.1.3. Selection of burrows: Within each location a hectare $(100 \times 100 \mathrm{~m})$ of high population of the species identified by examining the hot burrows (tracks and pellets) for two days. Each selected hectare was subdivided to four Iraqi donums (A, B, C, and D). The donum (A), which really had dense burrows investigated and random selection of five active burrows achieved.

\subsubsection{Collection of data:}

Descriptive features of burrows were the most important factors which focused, and divided into:

A. Soil surface parameters:

a. Spatial dispersion of randomly selected burrows.

b. The type of distribution (the pattern of dispersal).

Before excavation, the number of surface openings of each hot burrow system was recorded. We powered diluted red solution of mud into the openings around the hot burrows after recording their numbers, and distances from the main hot burrow. Vertical and horizontal axes are used for each burrow to determine their directions and inclination from the North. All measurements and directions were recorded and drawn on chart papers. We used the colored solution of mud to determine the tunnel digging system and secondary entrances; so by this way we performed sub-soil parameters.

B. Sub-soil parameters:

$$
1 \text { - Tunnel diameter }(\mathrm{cm}) . \quad 4 \text {-The }
$$
number of secondary entrances.

$$
2 \text { - Tunnel depth }(\mathrm{cm}) . \quad 5 \text { - Gallery }
$$
and tunnel digging system (manner of digging).

3- Pathway length $(\mathrm{cm})$. 6- Direction of digging.

C. Movement Dynamic Behavior of burrowing animal.

D. Food Source sites nearby experimental units.

\subsection{Laboratory work}

Soil samples took from 15, 30 and $45 \mathrm{~cm}$ depth, which achieved in Water and Soil Science Department, College of Agriculture, University of Duhok. Soil texture was examined by using USDA textural triangle, and subjected to the following:

1. Organic matter $(\%)$. 3. Bulk density $\left(\mathrm{g} / \mathrm{cm}^{3}\right)$. 5. Porosity (\%). 7. Silt \%.
2. $\mathrm{CaCO} 3(\%)$.
$\left(\mathrm{g} / \mathrm{cm}^{3}\right)$. 6. Sand $(\%)$.
4. Particle density

2.3. Data analysis

Selection of dependent and independent variables:

Independent variables: Edaphic factors and soil texture, which mentioned in laboratory work, selected as independent variables.

Dependent variables: Focusing on some tunnel dimensions as pathway length, total length, the depth, and the number of secondary entrances. Hence burrows with high parameters of these features can ensure better shelter for the 
burrowing animals, and qualify themselves for adaptation in that habitat.

We examined the relationship between dependent variables themselves; and between dependent and independent variables. Besides we tested the relationship between the interaction of independent variables and dependent variables to better know their effects on dependent variables by using Linear Multiple Regression Analysis by Stepwise Selection and using SAS software package and Pearson Correlation Coefficients.

\section{RESULTS}

\subsection{Identifying the species:}

1. Morphological features of the animal.

Total of (50) animals captured in each month, means 100 animals for two trials representing the species (A. flavicollis argyropuli) during the peak of a population in autumn, concretely in September and October. (Table1).

Table (1): Captured individual sexes found in spring wooden cage traps

\begin{tabular}{|c|c|c|c|c|c|c|}
\hline $\begin{array}{l}\text { Time of } \\
\text { capture }^{\star}\end{array}$ & $\begin{array}{c}\text { Number of } \\
\text { trials }\end{array}$ & Sumail & Girshin & Faishkhabour & $\begin{array}{l}\text { Engineering } \\
\text { college fields }\end{array}$ & Shawis \\
\hline \multirow[t]{2}{*}{ September } & $1^{\text {st }}$ trial & 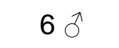 & 5 ๙ & 8 우 & $3 \hat{0}$ & 6 우 \\
\hline & $2^{\text {nd }}$ trial & 4 우 & $5 q$ & $2 \sigma^{\lambda}$ & 7 우 & $4 \hat{\jmath}$ \\
\hline \multirow[t]{2}{*}{ October } & $1^{\text {st }}$ trial & $3 q$ & 4 우 & $1 \delta^{\lambda}$ & $8+$ & $5 \overbrace{}^{\lambda}$ \\
\hline & $2^{\text {nd }}$ trial & $7 \lesssim$ & $6 \overbrace{}^{\pi}$ & $9 \circ$ & $2 \hat{\jmath}$ & $5 q$ \\
\hline
\end{tabular}

* Separate wooden traps used for each site.

Table 1 shows that individuals captured in the first trial were opposite in their sexes than the second trial. These data would appear to agree with the results obtained in
(Montgomery's, W.I., 1979) studies.

2. Using some biometric measurements.

All biometric measurements of the species for the five locations are seen in (Table 2).

Table (2): Biometric measurements of captured animals.

\begin{tabular}{|c|c|c|c|c|c|c|c|c|c|c|}
\hline \multirow[t]{2}{*}{$\begin{array}{c}\text { Biometric } \\
\text { measurements }\end{array}$} & \multicolumn{2}{|c|}{ Faishkhabour } & \multicolumn{2}{|c|}{ sumail } & \multicolumn{2}{|c|}{ Girshin } & \multicolumn{2}{|c|}{ Shawis } & \multicolumn{2}{|c|}{$\begin{array}{l}\text { Engineering } \\
\text { college fields }\end{array}$} \\
\hline & $\begin{array}{l}\text { Min- } \\
\text { Max. }\end{array}$ & Mean & $\begin{array}{l}\text { Min- } \\
\text { Max. }\end{array}$ & Mean & $\begin{array}{l}\text { Min- } \\
\text { Max. }\end{array}$ & Mean & $\begin{array}{l}\text { Min- } \\
\text { Max. }\end{array}$ & Mean & $\begin{array}{l}\text { Min- } \\
\text { Max. }\end{array}$ & Mean \\
\hline $\begin{array}{l}\text { Total length } \\
(\mathrm{mm})(\mathrm{TL} .)\end{array}$ & $\begin{array}{l}216- \\
224 \\
\end{array}$ & 220 & $\begin{array}{l}214- \\
222 \\
\end{array}$ & 218 & $\begin{array}{l}213- \\
220 \\
\end{array}$ & 217 & $\begin{array}{l}211- \\
215 \\
\end{array}$ & 213 & $\begin{array}{l}205- \\
210 \\
\end{array}$ & 208 \\
\hline $\begin{array}{l}\text { Tail length } \\
(\mathrm{mm})(\mathrm{T} .)\end{array}$ & $\begin{array}{l}100- \\
115\end{array}$ & 108 & $\begin{array}{l}98- \\
113\end{array}$ & 106 & $\begin{array}{l}98- \\
114\end{array}$ & 106 & $\begin{array}{l}89- \\
100\end{array}$ & 95 & $\begin{array}{l}80- \\
95\end{array}$ & 83 \\
\hline $\begin{array}{l}\text { Hind foot } \\
(\mathrm{mm})(\mathrm{HF} .)\end{array}$ & $22-25$ & 24 & $\begin{array}{l}20- \\
23 \\
\end{array}$ & 22 & $\begin{array}{l}21- \\
22 \\
\end{array}$ & 22 & $\begin{array}{l}20- \\
21\end{array}$ & 21 & $\begin{array}{l}19- \\
21\end{array}$ & 20 \\
\hline $\begin{array}{c}\text { Ear length } \\
(\mathrm{mm})(\text { E.)(c.u. })^{*}\end{array}$ & $\begin{array}{l}16- \\
23\end{array}$ & 18 & $\begin{array}{l}14- \\
20\end{array}$ & 17 & $\begin{array}{l}12- \\
21\end{array}$ & 17 & $\begin{array}{l}11- \\
20\end{array}$ & 16 & $13-18$ & 16 \\
\hline
\end{tabular}

$*($ c. u. $)=($ with claw $)$ included.

3. Observations on the entrances of burrows.

We experienced that the excavated soil usually was in contact with the entrances and not far from them for this species only in comparison to other rodent species there.

\subsection{Morphology and complexity of the burrows:}

Our investigations found that there were two types of burrows as follows: 
1-Simple burrow: Has the main entrance and one tunnel without branches as in Shawis in clay loam soils.

2-Complex burrow: Has the main entrance and one or more secondary entrances or tunnel branches as in the following sites:

a- Sumail: Complex burrows are found in clay loam, silt loam, silty clay, and silty clay loam soils, with a range of secondary entrances 1-2 entrances and a range of tunnel branches 2-3 branches.

b- Girshin: Complex burrows are found in clay soils, with a range of secondary entrances 1-3, and a range of tunnel branches 2-5.

c- Faishkhabour: Complex burrows are found in sandy clay, sandy clay loam, and sandy loam soils, with a range of secondary entrances $2-4$, and a range of tunnel branches 2-4.

d- Engineering College Fields: Complex burrows are found in clay loam, and silty clay soils, with a range of secondary entrances $0-1(0$ $=$ only the main entrance), and a range of tunnel branches 2-7. e- Shawis: Complex burrows are found in clay loam soils, with a range of secondary entrances $0-2$, and a range of tunnel branches 0-3 $(0=$ One tunnel without branches).

The simplest burrows were found in some Shawis patches, while the most complex burrows were found in Engineering College Fields.

Our field observations found also, that the same species (A. flavicollis argyropuli) can dig simple or complex burrows in the same and different soil types within a definite area.

\subsection{Distribution of burrows:}

We could determine the number of burrows, their main and secondary entrances, depths and pathway lengths for each sub-divided quarter (A, $\mathrm{B}, \mathrm{C}$, and D) of selected hectare for each location (Table 3).

\subsection{Data analysis:}

Tabulation of dependent and independent variables are taken place. Their mean, standard deviation, sum, minimum and maximum values are shown in (Table 4) and (Table 5).

Table (3) : Spatial distribution, depth, pathway length and number of entrances of the burrows.

\begin{tabular}{|c|c|c|c|c|c|c|c|c|}
\hline \multirow[t]{2}{*}{ Locations } & \multirow{2}{*}{$\begin{array}{l}\text { Depth }(\mathrm{cm}) \\
\text { mean }\end{array}$} & \multirow{2}{*}{$\begin{array}{c}\text { Pathway } \\
\text { Length(cm) } \\
\text { mean }\end{array}$} & \multirow{2}{*}{$\begin{array}{c}\text { \#of } \\
\text { Secondary } \\
\text { entrances } \\
\text { mean }\end{array}$} & \multicolumn{5}{|c|}{ \#of main entrances /ha } \\
\hline & & & & $\begin{array}{c}\text { Donum } \\
\text { A }\end{array}$ & $\begin{array}{c}\text { Donum } \\
\text { B }\end{array}$ & $\begin{array}{l}\text { Donum } \\
\text { C }\end{array}$ & $\begin{array}{c}\text { Donum } \\
\text { D }\end{array}$ & Total \\
\hline 1.Faishkhabour & 37.8 & 205 & 3 & 69 & 50 & 46 & 35 & 200 \\
\hline 2.Sumail & 30.0 & 236 & 2 & 55 & 48 & 40 & 37 & 180 \\
\hline 3.Girshin & 25.0 & 164 & 2 & 73 & 37 & 25 & 15 & 150 \\
\hline $\begin{array}{l}\text { 4.Engineering } \\
\text { College fields }\end{array}$ & 19.0 & 345 & 1 & 49 & 45 & 31 & 10 & 135 \\
\hline 5.Shawis & 20.0 & 150 & 1 & 35 & 31 & 28 & 26 & 120 \\
\hline
\end{tabular}

Table (4) : Dependent variables.

\begin{tabular}{lllllll}
\hline Variable & N & Mean & Std. Dev. & Sum & Minimum & Maximum \\
\hline Total length $(\mathrm{cm})$ & 25 & 299.52000 & 114.06289 & 7488 & 170.00000 & 610.00000 \\
\hline Pathway length $(\mathrm{cm})$ & 25 & 226.40000 & 81.10590 & 5660 & 140.00000 & 460.00000 \\
\hline Depth(\%) & 25 & 26.40000 & 9.39858 & 660.00000 & 16.00000 & 60.00000 \\
\hline $\begin{array}{l}\text { Secondary } \\
\text { entrances }(\mathrm{n})\end{array}$ & 25 & 1.64000 & 0.90738 & 41.00000 & 0 & 4.00000 \\
\hline
\end{tabular}


Table (5) : Independent variables.

\begin{tabular}{lllllll}
\hline Variable & N & Mean & Std. Dev. & Sum & Minimum & Maximum \\
\hline Sand $(\%)$ & 25 & 28.18000 & 20.51355 & 704.50000 & 10.10000 & 73.60000 \\
\hline Silt $(\%)$ & 25 & 33.02000 & 11.06913 & 825.50000 & 13.50000 & 50.25000 \\
\hline Clay $(\%)$ & 25 & 40.40000 & 11.97110 & 1010 & 17.90000 & 57.90000 \\
\hline Organic matter $(\%)$ & 25 & 2.48008 & 0.93092 & 62.00200 & 0.81000 & 3.86000 \\
\hline CaCO3 $(\%)$ & 25 & 29.58000 & 6.97866 & 739.50000 & 17.00000 & 38.50000 \\
\hline Bulk density $\left(\mathrm{g} / \mathrm{cm}^{3}\right)$ & 25 & 1.45600 & 0.11576 & 36.40000 & 1.20000 & 1.60000 \\
\hline $\begin{array}{l}\text { Particle density } \\
\left(\mathrm{g} / \mathrm{cm}^{3}\right)\end{array}$ & 25 & 2.54000 & 0.06455 & 63.50000 & 2.40000 & 2.60000 \\
\hline Porosity $(\%)$ & & & & & & \\
\hline
\end{tabular}

\subsection{Movement dynamic of burrowing animal:}

Three patterns of spatial dispersion distributions of burrows could be distinguished in studied areas as follows:

1. Insular distribution type (Sumail, Faishkhabour, and Shawis).

2. Cumulative distribution type (Girshin).

3. Unequal distribution type (Engineering College fields).

Additionally we could distinguish the permanent main food sources, the dynamic movement of go and fro paths and their directions within the studied hectare of each area were as follows:

Their walking paths and distances from hot burrows to food sources and vice versa were determined, by spraying fine soil around the burrows to get their footprints and their directions. Movement nets were drawn on chart papers.

Sumail: There was one food source (wastes of trees and vegetables), with a direction of
$\mathrm{S} 31 \mathrm{~W}$, and the distance range of burrows was 5$22.5 \mathrm{~m}$ far from the food source.

Faishkhabour: There was one food source (household trashes and cereals residue) with a South direction $180^{\circ}$, and the distance range of burrows was 7.5-22.5 $\mathrm{m}$ far from the food source.

Shawis: There was one food source (miscellaneous residues of residents) with a direction of $\mathrm{S} 15 \mathrm{E}$, and the distance range of burrows was $15-40 \mathrm{~m}$ far from the food source.

Girshin: There was one food source (cereals and vegetable residues) with a direction of $\mathrm{N} 038 \mathrm{E}$, and the distance range of burrows was 5-30 $\mathrm{m}$ far from the food source.

Engineering College fields: There were two food sources (cereal residues). The first one direction was $\mathrm{S} 41 \mathrm{~W}$, and the distance range of burrows closer to it was $12.5-13.75 \mathrm{~m}$, while the direction of the second one was $\mathrm{N} 28 \mathrm{~W}$, with a distance range $17.5-32.3 \mathrm{~m}$. (Table 6).

Table (6) : Spatial dispersion of burrows, and food sources of studied areas.

\begin{tabular}{cccc}
\hline Studied areas & $\begin{array}{c}\text { Type of spatial dispersion } \\
\text { of burrows }\end{array}$ & $\begin{array}{c}\text { Distance range from the } \\
\text { food source }(\mathbf{m})\end{array}$ & $\begin{array}{c}\text { Food source (n) /studied } \\
\text { area }\end{array}$ \\
\hline Sumail & Insular distribution type & $5-22.5$ & 1 \\
\hline Girshin & Cumulative distribution type & $5-30$ & 1 \\
\hline Faishkhabour & Insular distribution type & $7.5-22.5$ & 1 \\
\hline Engineering College fields & Unequal distribution type & $12.5-13.75$ & 1 \\
\hline Shawis & Insular distribution type & $17.5-32.3$ & 1 \\
\hline
\end{tabular}


The presence of the species in mentioned locations depended mainly on the food as main requirement of its life, but the spatial dispersion of burrows depended on the soil features and its ability to excavation. Rather than this we examined that burrow structure depended on soil horizon features.

\subsection{Burrow structure dimensions:}

Different dimensions experienced in different soil types within studied areas.

Pathway length: Longest pathway length (460 $\mathrm{cm})$ was seen in silty clay soils in Engineering College fields, and the shortest one $(150 \mathrm{~cm})$ was seen in clay soils in Girshin.

Total length: The longest total length (610 $\mathrm{cm}$ ) was seen in silty clay soils in Engineering
College fields, and the shortest one $(170 \mathrm{~cm})$ was seen in clay soils in Shawis.

Depth: Deepest burrow $(60 \mathrm{~cm})$ was seen in sandy clay loam soils in Faishkhabour, and the shallowest one $(16 \mathrm{~cm})$ was seen in clay loam soils in Engineering College fields.

The number of secondary entrances: The highest numbers of burrow secondary entrances (4) were seen in sandy clay loam soils in Faishkhabour, and the lowest one (0) was seen in clay loam soils in Engineering College fields.

\subsection{Relationships between variables:}

Relationships between dependent and independent variables, (Table 7):

Table (7) : Relationships between dependent and independent variables.

\begin{tabular}{|c|c|c|c|c|}
\hline Equation & $\beta 0$ & $\beta 1$ & $\beta 2$ & $R^{2}$ \\
\hline$\gamma 1=\beta 0+\beta 1 \times 4 \times 8+\beta 2 \times 2^{4}$ & 241 & -0.8737 & 0.00004 & 0.5121 \\
\hline P-value & $<.0001$ & .028 & .0001 & \\
\hline$\gamma 2=\beta 0+\beta 1 \times 4 \times 6+\beta 2 \times 2 \times 5$ & 285 & -30.611 & 0.00009 & 0.580 \\
\hline$P$-value & $<.0001$ & .024 & $<.0001$ & \\
\hline$\gamma 3=\beta 0+\beta 1 \gamma 4 \times 1+\beta 2 \times 5 \times 6$ & 31.87 & 0.10133 & -0.25545 & 0.706 \\
\hline P-value & $<.0001$ & $<0001$ & 0.0163 & \\
\hline$\gamma 4=\beta 0+\beta 1 \times 1 \times 2+\beta 2 \times 5 \times 8$ & 2.327 & 0.00106 & -0.00121 & 0.5252 \\
\hline P-value & 0.002 & 0.0036 & 0.0101 & \\
\hline
\end{tabular}

To get better R-square values, we applied the STEPWISE procedure on the interactions of independent variables to know their effects on the dependent variables. The relationship formulas are as follows:

a-The correlation between pathway length and the interaction of organic matter and porosity was negatively correlated, but (silt) ${ }^{4}$ had a positive effect on the pathway length of burrows, $(\mathrm{R}$-square $=0.5121, \mathrm{P}$-value $=0.0001, \mathrm{n}=25)$.

b-The correlation between total length and the interaction of organic matter and bulk density was negatively correlated, but (silt) 3 and $\mathrm{CaCO} 3$ had a positive effect on the total length of burrows, $(\mathrm{R}$-square $=0.5809, \mathrm{P}$-value $=<$ $0.0001, \mathrm{n}=25$ ).

c-The correlation between depth and the interaction of the number of secondary entrances and sand was positively correlated, but the interaction of $\mathrm{CaCO} 3$ and bulk density had a negative effect on the depth of burrows. (Rsquare $=0.7064, \mathrm{P}$-value $=0.0163, \mathrm{n}=25$ ).
d-The correlation between secondary entrances and the interaction of the sand and silt was positively related with the secondary entrances, but the interaction of $\mathrm{CaCO} 3$ and porosity had a negative effect on the number of secondary entrances of burrows. (R-square $=0.5252$, Pvalue $=0.00106, \mathrm{n}=25$ ) .

We endeavored to find out the relationship between dependent variables, by applying the Pearson Correlation Coefficients (r).

The strongest positive correlation shown between total length and pathway length $(\mathrm{r}=$ $0.86429)$ with highly significant $(\operatorname{Pr}>\mathrm{F}=<$ 0.0001 ), and slightly less correlation was obtained between depth and secondary entrances $(\mathrm{r}=0.66252)$ with highly significant also $(\mathrm{Pr}>\mathrm{F}$ $=0.0003)$, whereas the weakest was between total length and depth of tunnels.

-Relationships between dependent and independent variables:

The strongest positive correlation was shown between depth and sand $(r=0.64277, \operatorname{Pr}>F=$ 
0.0005), whereas the weakest was between total length and particle density $(\mathrm{r}=0.41866, \operatorname{Pr}>\mathrm{F}=$ 0.0373 )

\section{- Relationships between independent variables:}

Bulk density and porosity showed the strongest negative correlation with highly significant $(\mathrm{r}=-0.95701, \mathrm{Pr}>\mathrm{F}=<0.0001)$. Clay and organic matter showed the strongest positive correlation with highly significant, $(r=$ $0.70619, \mathrm{Pr}>\mathrm{F}=<0.0001)$ whereas the weakest was between clay and particle density.

-Somewhat high correlation also found between depth and the number of secondary entrances ( $\mathrm{r}$ $=0.66252)$, and highly significant $(\operatorname{Pr}>\mathrm{F}=$ $0.0003)$.

-We found positive correlation between total length and silt $(\mathrm{r}=0.46072)$, and $(\mathrm{Pr}>\mathrm{F}=$ $0.0205)$.

- Particle density showed positive correlation with porosity $(\mathrm{r}=0.47524)$, and $(\mathrm{Pr}>\mathrm{F}=$ 0.0164).

- Particle density showed positive correlation with total length $(\mathrm{r}=0.41866)$, and $(\mathrm{Pr}>\mathrm{F}=$ 0.0373 ).

- Silt showed positive correlation with pathway length $(r=0.47243)$, and $(\operatorname{Pr}>F=0.0171)$.

- Our investigations found that the silt had positive correlations with (pathway length, and total length), and negative correlation with the number of secondary entrances, which means, that has an ability to loosen the soil and accelerate digging.
- Also, we found a higher positive correlation between the number of secondary entrances and sand $(\mathrm{r}=0.50080)$, and $(\mathrm{Pr}>\mathrm{F}=0.0108)$, because of lesser energy cost to dig.

- Clay showed negative correlation with the number of secondary entrances $(r=-0.47858)$, and $(\mathrm{Pr}>\mathrm{F}=0.0155)$, because it hardens the soil.

- Negative correlation experienced between $\mathrm{CaCO} 3$ and the number of secondary entrances, because strengthen the bonds between aggregates of the soil, $(\mathrm{r}=-0.46903)$, and $(\operatorname{Pr}>$ $\mathrm{F}=0.0180$ ).

- We found strong negative correlation between sand and silt $(\mathrm{r}=-0.69726)$, and highly significant $(\mathrm{Pr}>\mathrm{F}=0.0001)$.

- The strongest negative correlation was found between sand and clay $(\mathrm{r}=-0.85138)$, and very high significance $(\mathrm{Pr}>\mathrm{F}=<0.0001)$.

-Sand showed strong negative correlation with organic matter $(\mathrm{r}=0.84595)$, and highly significant $(\mathrm{Pr}>\mathrm{F}=0.0001)$.

-Strong positive correlation found between silt and organic matter $(\mathrm{r}=0.64385)$, with highly significant $(\mathrm{Pr}>\mathrm{F}=0.0005)$.

- Stronger correlation can be seen between clay and organic matter $(\mathrm{r}=0.70619)$, and highly significant $(\mathrm{Pr}>\mathrm{F}=<0.0001)$.

- Weaker negative correlation found between clay and particle density $(\mathrm{r}=-0.42463)$, and $(\mathrm{Pr}$ $>\mathrm{F}=0.0344)$. (Table 8$)$ :

- Relationships between dependent variables, (Table 8): 
Journal of University of Duhok., Vol. 22, No.2 (Agri. and Vet. Sciences), Pp 9-24, 2019

Table (8) : Pearson Correlation Coefficient for dependent variables.

\begin{tabular}{|c|c|c|c|c|c|c|c|c|c|c|c|c|}
\hline & \multicolumn{12}{|c|}{$\begin{array}{c}\text { Pearson Correlation Coefficients, } \mathrm{N}=25 \\
\text { Prob }>|\mathrm{r}| \text { under } \mathrm{HO}: \mathrm{Rho}=0\end{array}$} \\
\hline & $\begin{array}{l}\text { Total } \\
\text { len.(cm) } \\
\end{array}$ & $\begin{array}{l}\text { Path. len. } \\
\text { (cm) }\end{array}$ & $\begin{array}{l}\text { Depth } \\
\text { (cm) }\end{array}$ & $\begin{array}{l}\text { Sec. ent. } \\
\text { (n) }\end{array}$ & $\begin{array}{l}\text { Sand } \\
(\%)\end{array}$ & $\begin{array}{l}\text { Silt } \\
(\%)\end{array}$ & $\begin{array}{l}\text { Clay } \\
(\%)\end{array}$ & $\begin{array}{l}\text { O. m. } \\
(\%)\end{array}$ & $\begin{array}{l}\mathrm{CaCO} 3 \\
(\%)\end{array}$ & $\begin{array}{l}\text { Bulk den. } \\
\left(\mathrm{g} / \mathrm{cm}^{3}\right)\end{array}$ & 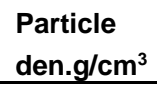 & $\begin{array}{l}\text { Porosity } \\
(\%)\end{array}$ \\
\hline$\stackrel{-1}{\stackrel{1}{\Phi}}$ & 1.00000 & & & & & & & & & & & \\
\hline \multirow{2}{*}{$\begin{array}{l}\overbrace{0}^{\circ} \\
F\end{array}$} & 0.86429 & 1.00000 & & & & & & & & & & \\
\hline & $<.0001$ & & & & & & & & & & & \\
\hline \multirow{2}{*}{ 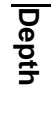 } & 0.00792 & 0.07877 & 1.00000 & & & & & & & & & \\
\hline & 0.9700 & 0.7082 & & & & & & & & & & \\
\hline \multirow{2}{*}{ 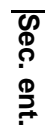 } & -0.12976 & 0.04960 & 0.66252 & 1.00000 & & & & & & & & \\
\hline & 0.5364 & 0.8139 & 0.0003 & & & & & & & & & \\
\hline \multirow[t]{2}{*}{$\begin{array}{l}\text { फ़ } \\
\text { ב્ڤ }\end{array}$} & -0.19220 & -0.16473 & 0.64277 & 0.50080 & 1.00000 & & & & & & & \\
\hline & 0.3574 & 0.4313 & 0.0005 & 0.0108 & & & & & & & & \\
\hline \multirow[t]{2}{*}{$\stackrel{\text { D }}{\Rightarrow}$} & 0.46072 & 0.47243 & -0.18642 & -0.10193 & -0.69726 & 1.00000 & & & & & & \\
\hline & 0.0205 & 0.0171 & 0.3723 & 0.6278 & 0.0001 & & & & & & & \\
\hline \multirow[t]{2}{*}{$\stackrel{\frac{0}{20}}{2}$} & -0.05641 & -0.09259 & -0.54245 & -0.47853 & -0.85138 & 0.32887 & 1.00000 & & & & & \\
\hline & 0.7888 & 0.6598 & 0.0051 & 0.0155 & $<.0001$ & 0.1085 & & & & & & \\
\hline ? & 0.03742 & 0.01179 & -0.51784 & -0.26554 & -0.84595 & 0.64385 & 0.70619 & 1.00000 & & & & \\
\hline$\stackrel{0}{\circ}$ & 0.8591 & 0.9554 & 0.0080 & 0.1995 & $<.0001$ & 0.0005 & $<.0001$ & & & & & \\
\hline \multirow{2}{*}{ 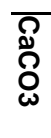 } & 0.14643 & -0.10235 & -0.45123 & -0.46903 & -0.15591 & 0.14943 & 0.32144 & -0.07550 & 1.00000 & & & \\
\hline & 0.4849 & 0.6264 & 0.0236 & 0.0180 & 0.4568 & 0.4759 & 0.1171 & 0.7198 & & & & \\
\hline \multirow[t]{2}{*}{$\stackrel{\text { 四 }}{\bar{x}}$} & -0.18974 & -0.21506 & -0.03677 & 0.23960 & 0.17175 & 0.34723 & -0.01052 & -0.15030 & 0.30369 & 1.00000 & & \\
\hline & 0.3636 & & 0.8615 & 0.2487 & 0.4117 & 0.0890 & 0.9602 & 0.4733 & 0.1400 & & & \\
\hline
\end{tabular}

amin.khedher@uod.ac 


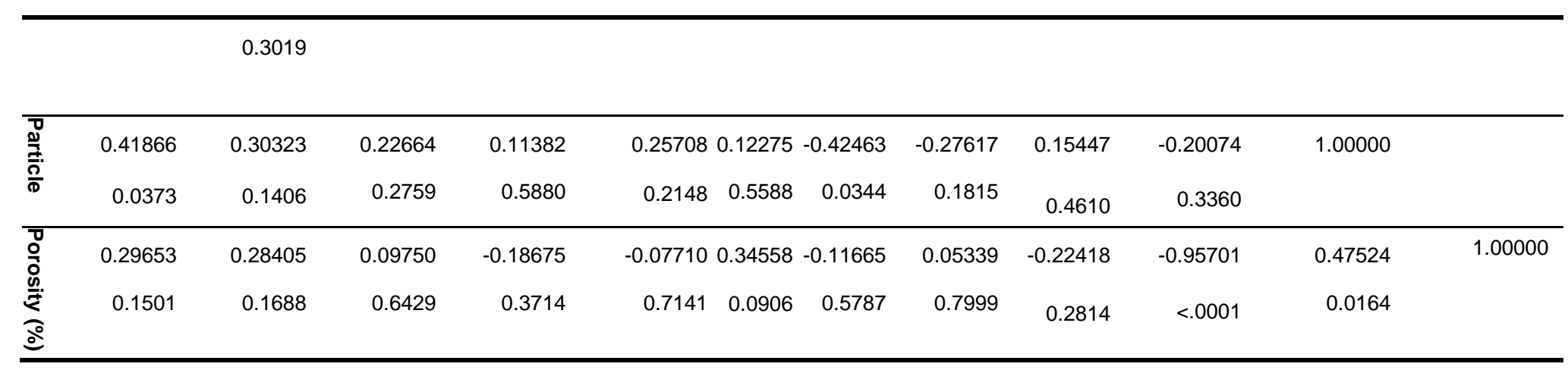

\section{DISCUSSION}

Burrowing animals usually take a benefit from some edaphic factors in their habitats, which mean that those factors can play a vital role in their geographical distribution (Alton E.K., 2006). Accordingly, those biotopes on where such burrows are found have to be taken into consideration (Vlasov, 1937).

\subsection{Morphology and complexity of the burrows;}

Morphological differentiation in burrowing or digging system can be attributed to the configuration of burrow site, soil horizon's properties, dimensions of digging system, and tortuosity of tunnels. This interpretation is agreed partially with (Jones et al., 1994), who related that to acoustics or longevity of the burrow. Our results support also (Alton, E. K., 2006), that the local edaphic factors play a large role in forming the burrow system.

Our observations stressed that the nomination of burrows as simple or complex depends mainly on the number of secondary entrances, and tunnel branches (whether opened or blind). Herein we agree with (Mankin \& Getz, 1994; Goyal and Ghosh, 1993; Brett, 1991), who turned the nomination to many aboveground entrances, and many underground interconnected tunnels. However, (Hinz et al., 2006) turned the nomination to the architectural variation of burrows.
We practiced in our study, that the complexity of tunnel systems in Engineering College Fields can be revealed to the presence of many predators and raptors like the jackal, stray dogs, cats, and common ravens. So the more entrances can confuse the predator for seeking the prey, which means more opportunity to escape through exit openings or concealing in some underground branches, and more complexity more safe from predators (Laundre, 1989). In addition to that, our observations in Engineering College fields noticed that the soil texture also played a large role to motivate the animal to create more tunnel branches whether opened or blind. Hence we saw that the range of tunnel branches was (2-7 branches), which were more than other studied areas. On the other hand, soil texture was clay loam and silty clay. Accordingly, we agree with the results of (Laundre and Reynolds,

1993), who attributed the complexity of burrows to the clay and silt content. Digging simple or complex burrows by the same species in a certain soil type depends on burrow site-specific features.

\subsection{Pathway length:}

The regression model for pathway length showed that $(51 \%)$ of the variation interpreted by the negative interaction of organic matter and porosity on the probability level (0.027), and positive effect with (silt)4 on the probability level(0.0001), (Table 7).

Pearson Correlation Coefficient showed that silt had positive correlation with pathway length $(r=0.47243)$, and $(\operatorname{Pr}>\mathrm{F}=0.0171)$, 
(Table 8).Laundry et al.1993, cleared in their work on Wyoming ground squirrels (Spermophilus elegans), that by increasing (silt $\%+$ clay \%), and decreasing (sand \%+bulk density), the depth, length and the complexity of the burrows will be more. The same authors in their work on Kangaroo rat (Dipodomys ordii), found that, in case of increasing (silt\% + clay $\%)$, the volume, length, and complexity will be greater.

But in the Deer mice (Peromyscus maniculatus), they found that, in case of increasing (bulk density + clay \%), (length + volume) will be increased. Others as Dirk $\mathrm{H}$. Van Vuren Miguel (A. ordeñana), 2012, found that body size was positively correlated with burrow length, and depth. Our and mentioned results refers to the vital role of silt in loosening the soil and accelerating the digging within studied animals. We experienced in our study, that there are many variations in burrow structure dimensions within the studied species, (Table 9), which agree with that of Dirk H. Van Vuren Miguel (A. ordeñana), 2012, Reichman and Smith 1989, and Anderson and Allred 1964, Reynolds and Wakkinen 1987.

Both the length and depth of burrows in our study were not affected by soil bulk density and sand, e.g. (Laundré and Reynolds 1993), in their study on Great Basin ground squirrels (Urocitellus mollis). The longest pathway and total lengths of burrows were $(160-460 \mathrm{~cm})$, and $(280-610 \mathrm{~cm})$, respectively in silty clay soils in Engineering College fields. While the deepest burrows and greatest numbers of secondary entrances were found in sandy clay loam soils in Faishkhabour.

Table (9): Range dimensions of burrow structure for studied areas.

\begin{tabular}{lccccc}
\hline \multirow{2}{*}{$\begin{array}{l}\text { Burrow } \\
\text { structure }\end{array}$} & \multicolumn{3}{l}{ Range of dimensions for studied areas } & & Shawis \\
\cline { 2 - 6 } & Sumail & Girshin & Faishkhbour & $\begin{array}{c}\text { Engineering } \\
\text { College fields }\end{array}$ & Clay \\
\cline { 2 - 6 } & Silty clay & Clay & $\begin{array}{c}\text { Sandy clay } \\
\text { loamy }\end{array}$ & Silty clay & $140-220$ \\
\hline Pathway length $(\mathrm{cm})$ & $190-370$ & $150-190$ & $160-280$ & $280-610$ & $170-260$ \\
\hline Total length $(\mathrm{cm})$ & $245-385$ & $195-255$ & $210-345$ & $16-23$ & $18-23$ \\
\hline Depth $(\mathrm{cm})$ & $18-35$ & $20-30$ & $28-60$ & & $0-1$ \\
\hline $\begin{array}{l}\text { No. of secondary } \\
\text { Entrances }(\mathrm{n})\end{array}$ & $1-2$ & $1-3$ & $2-4$ & $0-2$ \\
\hline
\end{tabular}

\subsection{Total length:}

The regression model for the total length, showed that $(58 \%)$ of the variation in the total length caused by the negative interaction between organic matter and bulk density on the probability level $(0.24)$ and positive interaction of (silt) 3 and $\mathrm{CaCO} 3$ on the probability level $(<$ $0.0001)$. The negative correlation of the interaction between organic matter and bulk density is caused by the presence of bulk density, which strengthens the soil, and it will be difficult to dig by the animal, e.g. Ohu et al.1985, who demonstrated, that increases in soil bulk density are accompanied by increases in soil strength properties. Values of bulk density decreased with increasing organic matter contents at most levels of moisture content in all the soils, Edwin, I. E., and R. J. Stone. 2015. Organic matter reduces soil compatibility by increasing the stability of the soil and also by retaining greater soil moisture which cushions soils against compaction (Paul, 1974).The strongest correlation was found between total length and pathway length because the total length is the sum of all branches of the burrow.

\subsection{Depth:}

The regression model for the depth, showed that $(70 \%)$ of the variation in the depth caused by the positive interaction of the number of secondary entrances and the sand on probability 
level $(<0.0001)$, and the negative interaction of $\mathrm{CaCO} 3$, and bulk density on the probability level (0.0163)

Sand showed a strong positive correlation with depth, whether separately or when interacting with other factors. Here we agree with John W. Laundry,l, and Timothy D. Reynolds. 1993, when they return the reason for the depth of Montane vole (Microtus montanus) to the high sand \%, as can be easily excavated. Reichman O. J. and Smith S. C. 1990 indicated that burrow dimensions depend mainly on the physical properties of soil to resist excavation by the animal with fewer energy costs.

\subsection{Number of secondary entrances:}

The regression model for the number of secondary entrances showed, that $(52 \%)$ of the variation in the number of secondary entrances caused by the positive interaction of sand and silt on the probability level (0.0036), and the negative effect of $\mathrm{CaCO} 3$ and porosity ratio on the probability level $(0.01)$, because it hardens the soil and the animal finds difficult to dig, as O.J. and Smith S.C. 1990.

\subsection{Pearson Correlation Coefficient (Table8):}

Pearson Correlation Coefficient showed the strongest negative correlation between bulk density and porosity $(\mathrm{r}=-0.95701)$ and highly significant $(\operatorname{Pr}>\mathrm{F}=<0.0001)$. This result agrees with (Pabin et al., 1998), who found inverse correlation between bulk density and soil porosity, and cleared that an excessive bulk density increases penetration resistance, reduces aeration and may limit root growth. Pearson Correlation Coefficient showed the strongest positive correlation between total length and pathway length $(\mathrm{r}=0.86429)$ and highly significant $(\mathrm{Pr}>\mathrm{F}=<0.0001)$ because the total length is the sum of all tunnel branches.

\subsection{Number of burrowing systems:}

Our results turned the presence of different numbers, and dispersion types of animal burrow in different sites, to the food source, soil horizon properties, and the priority of the site in fulfilling the life requirements of the animal, as opposed to (Shump, 1976) that turned that to the soil texture only. We partially support ( Gholamreza N.et., al., 2011), who stated, that the burrow site selection depends mainly on the percentage of plant canopy, vegetation type, soil texture and chemical properties of soil.

\subsection{Proximity of burrows to food sources:}

The food is one of the most important life requirements, which attract any animal elsewhere to its sources. We experienced that permanent food assemblages were the most motivated factor for animal to be there as shown by Anna et. al. 2009, that (A. flavicollis) is very sensitive to the availability of food in its habitat. The animal endeavors to dig nearby food sources depending on excavation ability of the soil especially in spring. Different ranges of distances within each location (Faishkhabour 7.5-22.5 m; Girshin 5-30 m; Sumail 5-22.5 m; Engineering College fields 12.5-13.75 m, 17.5$32.3 \mathrm{~m}$; and Shawis $15-40 \mathrm{~m})$ refers to site specific features of each soil type, which results the mentioned distances between burrows and food sources.

The animal wants to be closer to the food source to fulfill his food requirements through reaching the area in shortest time, fewer costs like decrease consuming energy while feeding there in severe weather (Van Aarde et al., 1992), and getting more food with the best quality (Jackson, 2001).

\subsection{Spatial dispersion of burrows:}

The most effective motivator agent, that obliges the animal to disperse or isolating in small patches, is the anthropogenic agent, which disturb those animals especially by using or removing their habitats (Merryl G. et al., 2007). We saw that site-specific features, plant canopy, and soil characters played a large role in selecting burrow sites for the studied areas e.g. (Naderi G.et al., 2011), which allowed the studied species producing three types of spatial distributions as:

\section{-Insular distribution type:}

This type was experienced in Sumail, Faishkhabour, and Shawis.

Sumail is characterized by the presence of one food source consisted of agricultural residues of vegetables and trees, and the burrows are restricted within edges and ecot.ones in adjacent to the food source. While in Faishkhabour, the burrows are dominated in some insulated patches with a permanent canopy of some biennials and small perennials closer to the food source (household trashes and residues of cereals). But in Shawis, the situation is differing. The loose soils are isolated by rocky substrates, on where are occupied by burrows within miscellaneous food source boundaries. 


\section{-Cumulative distribution type:}

This type is found in the Girshin population, which has one food source, consisted of agricultural and cereal residues, that are thrown there periodically forming a large permanent assemblage of wastes. Different predators as stray dogs, cats, and common ravens are usually attracted to that place compete for the current rodents on food causing this type of distribution. So this type of distribution can be turned to the presence of a large amount of food every time with good quality also (agricultural and house residues). Hence, this distribution +will be more beneficial to the animal than others, (Pulliam and Caraco, 1984; Krause and Ruxton, 2002). The cumulative effect of such aggregation will be better for the animal to get more territorial information, and decrease the predator's impact, (Robert, 1988; Davies et al., 2012). We agree somewhat with (Rimvydas J., 2002) in his work on (A. flavicollis), that the patterns of spatial distribution of this species in large forested areas were largely dependent on availability of food, and found three distributions for this species, which may be random, aggregate and regular if the relative abundance of the animal was the same for sequential years in large forest areas. Such type of dispersion is also experienced by (Alton E.K., 2006) with gopher tortoise in oak scrub in upland communities of central Florida.

\section{- Unequal distribution type:}

Engineering college fields characterized by this pattern of dispersion, which may be ascribed to the presence of two main food sources of cereals and other agricultural residues, and many other secondary sources with different quantities and qualities scattered here and there, which present in irregular periods. Our data may be in concordance with (Rimvydas J., 2002), in which he stated two different situations related to $(A$. flavicollis) in large forest areas. The first is that, by the stability of relative abundance of $(A$. flavicollis) in sequential years, the spatial distribution of the species be random, and aggregated as well as regular. The second state is, in case of food rarity, the spatial distribution is tended to be regular. On the other hand, Horváth G.et al., 2005, referred to an even distribution type of (A. agrarius), and (A. flavicollis) in a protected forest. Besides (Győző F. et al. 2012) cleared that, the habitat use of the (A. agrarius) and (A. flavicollis) was equal in a floodplain forest. Accordingly, the regularity in the availability of food plays a crucial role in forming the pattern of spatial distribution of the fossorial animal.

The current study showed that the spatial distribution type depends on the quantity, quality as well as the distribution of food sources in different sites.

Different burrow dimensions were experienced in different soil types. Higher dimensions were differentiated in Faishkhabour.

\subsection{Movement dynamic of animal:}

We found that, the tendency of dominant movement direction to the residue assemblages can be attributed to the fulfillment of their food and shelter requirements; here we support (Jackson, 2001) in his interpretation.

Our research highlights: The need of taking other factors in consideration like working on larger experimental units to increase the replications, site factors, microclimate, soil horizon's properties, predators and raptors, the animal physical potential to dig, and the animal size to get better results.

\section{Conclusion}

As the research has demonstrated, yellownecked field mouse is already present in field crop biotopes. The availability of food sources in different sites can easily attract such rodents to dig burrows there. Burrows spatial distribution can be affected by soil horizon properties and porosity in fulfilling the burrow requirements. Site-specific features and local edaphic factors, especially soil texture play a crucial role in burrow morphology and complexity. The burrowing animals usually take a benefit from those edaphic factors which can serve them better in their habitat and tend to go safely to the nearest food source in shortest time and consuming less energy. Moreover, the configuration of burrow sites, soil horizon's properties, dimensions of digging systems and tortuosity of tunnels are the most motivating factors for the morphological differences in digging systems.

\section{Acknowledgement}

This work was supported and funded by the College of Agriculture, University of Duhok. We thank the laboratory staff of the Department of Soil and Water Sciences in the college, for their contribution in analyzing soil samples. We thank the collaborating colleagues of the college for the contribution to analyzing the data. 


\section{REFERENCES}

Abdul-Husain, H. K., (1994). Rodents Control. Science. Encyclopedia 17: 217.Freedom Publishing Press, 40, 44, (in Arabic). 218.

Abs. Works Zool. Inst. Moscow State Univ...3: 103.

Alton, E. K. (2006).Burrows of semi-fossorial vertebrates in Upland communities of Central Florida: Their architecture, dispersion, and ecological consequences. Ph. D. Dissertation. University of Florida. Florida, United States of America.

Amori, G.; Hutterer, R.; Kryštufek, B.; Yigit, N.; Mitsain, G.; Palomo, L. J. (2008). "A. flavicollis". IUCN Red List of Threatened Species. Version 2013.1. International Union for Conservation of Nature. Retrieved 2013$10-10$.

Anderson, A. 0., and D. M. Allred, (1964). Kangaroo rat burrows at the Nevada Test Site. Great Basin Naturalist 24:93-101

Anna Stradiotto, Francesca, Cagnacci, Richard Delahay, Silvia Tioli, Luis Nieder, and Annapaola Rizzoli. (2009). Spatial organization of the yellow-necked mouse: effects of density and resource availability. 2009. Journal of Mammalogy, 90(3):704-714, 2009.

Brett, R. A. (1991). The ecology of naked mole-rat colonies: burrowing, food, and limiting factors. In: The biology of the Naked Molerat. Ed. By: P. W. Sherman J. U. M.

Davies NB, Krebs JR, West SA. (2012). An Introduction to Behavioral Ecology. Wiley Blackwell, Oxford.

Dirk H. Van Vuren and Miguel A. Ordeñana. (2012). Burrow dimensions of ground squirrels, with special reference to the California ground squirrel. The California Department of Water Resources (Contract No. 4600008761) and the Sacramento Area Flood Control Agency (Contract No. 984).

Edwin, I. E., and R.J. Stone. (2015). Organic matter effects on the strength properties of compacted agricultural soils. Transactions of the ASAE. American Society of Agricultural Engineers. January 1995. Vol. 38(2):357-365.

Ellerman, JR. Morrison-Scott, TCS. (1951). Checklist of Palearctic and Indian 219 Mammals; 1758 to 1946.The British Museum (N. H.), London. 220.

Erick G. B. \& W. L. Robinson. (2003). Wildlife ecology and management, 221.

Fifth edition, Prentice Hall, Pearson Education, Inc. Upper Saddle River, New Jersey 22207458. 247-253. 223.

Gholamreza N., Mahmoud R. H., Saeed M., Borhan R., Mahmoud K., Mahmoud K., Ali A. A. (2011). Effect of vegetation and soil conditions on burrow structure and the selection of rare desert rodent-Iranian jerboa (Allactaga firouzi). Polish Journal of Ecology. 59(2): 403-411.

Goyal, S. P., and Ghosh, P. K. (1993). Burrow structure of two gerbil species of Thar Desert, India. Acta Theriologica, 38:453-456. Hinz A., Pillay N. \& Grab, S.

Győző F. Horváth. Dávid Schaffer, Ákos Pogány, and Dániel Tóth. (2012). Spatial distribution of small mammal population in Drava Floodplain Forests: Sumarski list, 3-4, CXXXVI (2012), 141-151.

Hábil, H. P. (Forditotta: Dr. Jánossy D., Zsilinszky S.). (1973). Uránia 224 Állatvilág - Emlősok, Második Kiadás, Gondolat Kiado Budapest (1973), 173-175. 225 Page: 18 of 22.

Harisson and Bates, 1991. ITIS - Integrated Taxonomic Information System- Report: Taxonomic Serial No. 585139

https://www.itis.gov/servlet/SingleRpt/SingleRpt?sea rch_topic=TSN\&search_value=585139\#null/

Heptner, (1948). A. ponticus. Mammal species of the world, Wilson \& Reeder's.( $3^{\text {rd }}$ ed.) Johns Hopkins University Press ISBN 978-0-80188221-0 OCLC.

Hinz, A., Pillay, N. \& Grab, S. (2006). The burrows of the African ice rat (Otomys sloggetti robertsi). Mammalian Biology, 71:356-365

Horváth G., M. Dávid \& Cs. Gergely, (2005): Population dynamics and spatial pattern of small mammals in protected forest and reforested area. Natura Somogyiensis 7-191207, Kaposvár, 2005.

info@themmalsociety.org www.mammal.org.uk 023 8023 7874. Species Factsheet: Yellow-necked Mouse (A. flavicollis). 
ITIS - Integrated Taxonomic Information SystemReport: Taxonomic Serial No. 585139

https://www.itis.gov/servlet/SingleRpt/SingleRpt?sea rch_topic=TSN\&search_value $=585139 \#$ null/

Jackson, T. P. (2001). Factors influencing food collection behavior of Brant's whistling rat (Parotomys brantsii): a central place forager. Journal of Zoology (London), 255:15-23.

Jalil, A. A. (1987). Agricultural rodents: their damages and control, General 226.General Body of Training and Agricultural Extension Publishing Press, 31-32 (in Arabic). 227.

Jones, C. G., J.H., Lawton, and M. Shachak. (1994). Organisms as ecosystem engineers. Oikos, 69: 373-386 Kay FR, Whit ford WG. 1978. The burrow environment of the banner-tailed kangaroo rat, Dipodomys spectabilis, in SouthCentral New Mexico. American Midland Naturalist 99 (2):270-279.

Konig, Claus (1973). Mammals. Collins \& Co. pp. 127-130. ISBN 978-0-00-212080-7.

Krause, J, Ruxton GD. (2002). Living in groups. Oxford University Press, Oxford.

Laundre, J.W. (1989). Horizontal and vertical diameter of burrows, of five small mammal species in Southeastern Idaho. Great Basin Naturalist, 49: 646-649.

Laundre, J.W., and Reynolds. (1993). Effect of small mammal burrows on the water infiltration in a cool desert environment. Oecologia 94: 43-48.

Laundré, J. W., and T. D. Reynolds. (1993). Effects of soil structure on burrow characteristics of five small mammal species. Great Basin Naturalist 53:358-366.

Mankin, P. C., \& Getz, L. L. (1994). Burrow morphology as related to the social organization of Microtus ochrogaster. Journal of Mammalogy, 75: 492-499.Nel, J. A. J. 1967.Burrow systems of Desmodilus auricularis.

Merryl, G., D. W. Macdonald, F. Mathenus.(2007). Are hedgerows the route to increased farmland small mammal density? Use of hedgerows in British pastoral habitats: Landscape Ecol.2007. 22: 1019-1032. D01.10, 1007 / S 10984-007-9088-4.
Michal K. (1976), Migratory tendencies in a population of bank voles and description of migrants 228, ACTA Theriologica, Vol. 21, 24: 321-338, 1976, 323. 229.

Montgomery, W. I. (1979). An examination of interspecific sexual and individual biases affecting rodents captures in Long worth Traps, ACTA Theriologica. vol. 24, 3: 35-45, 1979, 35.

Musser, G.G.; Carleton, M.D. (2005). "Superfamily Muroidea". In Wilson, D.E.; Reeder, D.M (eds.). Mammal Species of the World: A Taxonomic and Geographic Reference (3rd ed.). Johns Hopkins University Press. p. 1265. ISBN 978-0-8018-8221-0. OCLC 62265494.

Naderi G., Hemami M., Mohammadi S., Rienzi B., Karami M., Kaboli M., and AL sheikh A. (2011).Effect of vegetation and soil conditions on burrow structure and site selection of rare desert rodent-Iranian jerboa (Allactaga firrouzi). Polish Journal of Ecology, 2011. Vol. 59, No.2 pp. (403-411).

Ohu, J.O., G. S. V. Raghavan and E. Mckyes. (1985). Peat moss effect on the physical and hydraulic characteristics of compacted soils. Transactions of the ASAE 28(5):420-424.

Ostfeld, R. S. (1990). The ecology of territoriality in small mammals. Trends in Ecology \& Evolution 5:411-415.

Pabin, J., J. Lipiec, S. Wlodek, A. Biskupski, and A. Kaus. (1998), Critical soil bulk density and strength for pea seedling root growth as related to other soil factors. Soil Tillage Res. 46:203-208.

Paul, C. L. (1974).Effects of filter-press mud on soil physical conditions in sandy soil. Tropical Agric. (Trinidad) 51(2):288-292.

Pulliam, HR., and T. Caraco. (1984). Living in groups: is there an optimal group size. In: Krebs JR, Davies NB (Eds.) Behavioral Ecology: An Evolutionary Approach. Vol. 2. Blackwell Scientific Publications, Oxford, pp. 122-147.

Reichman, O. J., and S. C. Smith, (1989). Burrows and burrowing behavior by mammals. Pages 197-244 in H. H. Genoways ed., Current Mammalogy. Vol. 2. Plenum Publishers, New York. 
Reichmann, OJ. , and Smith, SC. (1990). Burrows and burrowing behavior by mammals. In: Genoways HH (ed.) Current Mammalogy. Plenum Press, New York, pp. 197-244.

Rimvydas, J. (2002). Spatial distribution of yellownecked mouse (A. flavicollis) in large forest areas and its relation with the seed crop of a forest. Mammal Biol.: 67. 2002. 206-211.

Robert E. Martin, Ronald H. Pine, \& Anthony F. DE Blasé (2001). A Manual of Mammalogy With Keys to Families of the World, $3^{\text {rd }}$. edition, McGraw-Hill Book Co.

Robert, T. H., (1959). The Mammals of Iraq. Miscellaneous Publications, Museum of Zoology 233, University of Michigan, No. 106. February 12, 1959. 84- 85. 234.

Robert, SC. (1988). Social Influences on Vigilance in rabbits. Animal Behavior 36:905-913.
Shump, K.A., Jr. (1976). Ecological importance of nest construction in the hispid cotton rat Sigmodon hispidus. Ph.D. dissertation, Michigan State University. East Lansing. MI. $106 \mathrm{pp}$.

Széky, P. (1983). Okológia Kislexikon, Natura Hungary, 16, 34-35.

Van Aarde, R.J., Willis, C.K., Skinner, J.D. and Haupt, M.A. (1992). Range utilization by the aardvark, Orycteropus afer Pallas, (1766) in the Karoo. South Africa, 22:387-394.

Vlasov, Y. (1937). The burrow: as a particular biotope in the vicinity of Ashkhabad in Russian. In: Problems of the parasitology and fauna of Turkmenia. Press of the USSR Academy of Sciences, pp. 223-240. Moscow Leningrad. Original not seen, quoted from Krivokhatskiy, V. undated Repetek SandDesert Station and Reserve, Institute of Deserts, USSR Academy of Science. 